\title{
LANGUAGE, MARGINALITY AND EDUCATION: A GITANO CASE STUDY
}

\author{
Por \\ Rogelio Reyes*
}

\section{RESUMEN}

Dadas las obras de Skutnabb-Kangas, Fishman y Keller, etc., sobre la educación de las minorías linguísticas en diferentes partes del mundo, parecería apropiado incluir, en la discusión que se sigue sosteniendo a través de revistas y otras publicaciones, estudios sobre la educación de una minoría sobremanera descuidada, es decir el pueblo Rom o, como se les conoce en España, los gitanos. El presente artículo trata de dar una visión microcósmica de la relación entre el lenguaje, la condición social y la educación de este grupo a través de un estudio de caso de dos gitanos en Barcelona.

Se concluye que, a pesar de que nuestros contemporáneos gitanos se encuentran más integrados en ciertos aspectos a la sociedad española que en los tiempos anteriores, su marginación social y educativa, en esencia, persiste. En el contexto de esta conclusión, surge una pregunta más general: ¿son de hecho las diferencias linguísticas de los grupos marginados ( $v . g r$. los indígenas de Latinoamérica, los chicanos de Estados Unidos, etc.) las que impiden su progreso educartivo social, o se debe esto a factores más básicos y estructurales? La experiencia de los gitanos parece apuntar hacia la segunda conclusión.

\section{ABSTRACT}

Given the works of Skutnabb-Kangas (1981) Fishman \& Keller (1982) and others on the education of linguistics minorities in different parts of the world, it would appear proper to include, in the on-going discussion through journals and other publications, an account of the education status of yet another much neglected minority -the Rom, or Gypsies, as they are commonly know in English. The present study attemps to give a microcosmic view of the common rubric for the Rom in Spain.

* An Associate Professor with a Ph. D. in Linguistics from Harvard University. Dr. Reyes is a researcher of human culture, linguistics and worldwide languages. San Diego State University, Imperial Vally Campus.

Profesor asociado de San Diego State University. Imperial Valley Campus. Doctorado en lingüística por la Universidad de Harvard, es un investigador de antropología cultural en lo general, y de lingüística e idiomas a nivel mundial. 


\section{LANGUAGB, MARGINALITY AND EDUCATION}

It is concluded that although modem-day Gitanos are linguistically and otherwise more integrated in Spanish society than in previous times, they remain, for the most part, educationally and socially marginalized. This conclusion raises the general question: Is it language differences alone that keep marginal group (e.g. indígenas in Latin America, Chicanos in the United States, etc.) from attaining educational and social equality or does their marginal status depend on other, more structural factors as well? The Gitano experience seems to indicate that the latter is the case.

\section{INTRODUCTION}

The popular notion, in the United States at least, is that the language differences of ethnic minorities constitute a hidrance to their attainment of education equality and consequently of their integration in the mainstream society. In order to investigate the concrete validity on this assumption, the present study examines the microcosm of two members of an ethnic minority in Spain. Admittedly, a case study cannot be considered conclusive. It can, however, point out the direction for future study.

The social condition of Gitanos in Spanish society is well researched and their marginality needs no further corroboration. Leblon's (1987:78) in-depth study of this group summarizes it as follows:

"Cierto es que el fenómeno [i.e. Gitano marginality] no es privativo de Cataluña, y hallaremos gitanos viviendo en miserables barracas en la periferia de todas las grandes ciudades."

In the following sections I present 1) theoretical prolegomena to the study of marginality; 2) certain hypotheses relating to the lingustic and social status of the Gitanos; 3) concrete data based on two case studies conducted in Barcelona in 1988; and 4) my conclusions, relating the data to my hypothesis.

\section{THE CONCEPT OF MARGINALTTY}

Ohmann (1986:292) defines the concept of class in terms of a group's basic relation to production. Any other definition, he claims -for example in terms of income, education, occupation, etc.- is in reality merely a manipulation of the variables, which may be substituted at will, thereby changing the actual membership of each class also at will.

Although Ohmann proposes a Marxian view of class as a better alternative, my point in citing him here is simply to argue that the factors that constitute marginality might also be similarly manipulated in order to explain away the concept itself. I therefore follow Ohmann and claim that the concept of class (and by extension, 
marginality) should be grounded "....in basic relations of production" (1986:292). Obviously the social indicators of marginality as seen in income, housing, education, language, etc. are also important, but they should not constitute the basis for the definition of the concept per se. The fundamental factor $-\mathrm{a}$ group's basic relation to production-will constitute the basis of my study of marginality.

\section{The measurement of marginality}

In my research with the Gitanos, I have found it necessary to make a distinction between moderate and extreme marginality. This distinction entails a concomitant participation and non-participation in the labor force, respectively.

Extreme marginality implies isolation from the productive and consumer -processes of society. Thus the problems of income, housing, education and, by extension, culture in general which are part of the every day life of the working class are largely irrelevant to extremely marginalized groups. ${ }^{1}$ This characterization, as we shall discuss below, seems to have been the one befitting the early Gitanos in Spain.

Moderate marginality, on the other hand, implies that the affected group is part of a society's working class but relegated to the latter's fringes. It performs the most menial work necessary for the maintenance of society -as unskilled labor, petty vendors, junk collectors, etc. The Gitanos, again-in this instance those of modern times-constitute an example of this condition.

Thus, the moderately marginalized are caught up in the "wheels of production" and must grapple with these social problems whether they want to or not. This fact gives rise to the symbolic anecdote, recounted by my informant R.M., of the Gitano trying to cope with his horse and his fifth story apartment at the same time. Under "The significance of marginality in the study of language" below I shall discuss how this same fact affects the language of the Gitanos.

Given the grounding of marginality in the basic relations of production as explained above, it is obvious to me that no magic formula based on the usual social indicators of income, housing, education, etc. can be invoked to provide a quantitative method of determining marginality. Marginality is a phenomenon of degree rather than a binary $[+]$ or $[-]$ feature.

\footnotetext{
${ }^{1}$ This should not be interpreted to mean that the extremely marginalized do not have problems of their own. But these problems are situated within a different framework than those of the rest of society. Income, for example is not directly related to the solution of these problems since the group lives outside the monetary economy of that society.
} 
Nevertheless, if we intend to use marginality as a concept in social analysis, we need to have some way of determining whether a group is or is not in fact marginalized.

In response to this problem, it must be said that marginality should be invoked only in the clearest of cases. Grey areas should be approached with extreme caution. In the case of Chicanos in the United States, for example, although they, as a group, are definitely a working-class segment of society, the question of their marginality is an open one -there seem to be gradations of reduced participation in society within the group as a whole and the linguistic reflections of this fact are correspondingly complex. Accordingly, the concept of marginality will probably have only limited application and validity-e.g. among migrant farmworkers.

The case of the Gitanos, on the other hand, is much clearer. Most of the research on this group -e.g. Leblon (1987), San Román (1976), etc. as well as the Gitano movement literature- e.g. Ramírez Heredia $(1983,1985)$ Torres Fernández (1987), the biweekly newspaper Nevipens romani, etc. -indicates that modern Gitanos, mainly urban dwellers, are second-class citizens excluded from full participation in Spanish society.

\section{The significance of marginality in the study of language}

According to Donahue (in press), “...no marginalized mother tongue... may survive in the presence of a language of wider communication..." The validity of Donahue's axiom as it applies to the language of the Gitanos will be exploted in this and the next section.

In the study of languages in general, some -like certain Native American languages ( $c f$. Leap 1984)- have been seen to survive as an integral part of the speakers' culture although the group as a whole may live quite "marginalized" or isolated from the mainstream society.

This survival of a language in spite of its marginal condition might be interpreted to contradict Donahue's axiom. Since marginality, however, is a matter of degree, as I have stated above, I believe we can still demonstrate the truth of this axiom provided we exclude from its application the condition of extreme marginality. In the latter case, the marginalized group, although embedded in the larger society, lives in relative isolation and is thus able to preserve aspects of its traditional culture-including language-more easily than when it is in closer contact and involved with the dominant society.

This, in fact, was the case with the Gitanos in the early period of their existence in Spanish. Originally from India, they wandered as nomadic tribes into Europe, including Spain, in the XV century and continued their relative isolation from 


\section{Rogelio Reyes}

Spanish society for a period of time thereafter. During that initial period, their traditional culture, including their language, was more integrally preserved than later.

An official policy of extermination of their way of life, however, beginning in 1944 with the repressive Pragmática de Medina del Campo, forced Gitanos to "integrate" into Spanish society. This policy created their present condition, which I consider moderate marginality as opposed to their extreme marginality of the ourly period.

This perspective implies that marginality is not necessarily deleterious to the culture of the marginalized group. In fact, extreme marginality may actually aid in the preservation of its culture. this seems to have been the case of the Gitanos during their early period in Spain, and perhaps of the present day more isolated Native American communities as well.

Moderate marginality, on the other hand, almost inevitably implies erosion of the traditional culture without the usually concomitant benefits of full integration into the dominant society. Again, the example of the Gitanos, in modern times, seems to exemplify this condition.

Without the concept of marginality, phenomena such as language maintenance and language loss, for example, may be attributed to a variety of causes -language attitudes, language loyalties, loss of the traditional "non-verbal" culture, as in Donahue (in press), etc.- but the material basis of these "causes" in the affected group's relation to production is usually overlooked. This oversight, it seems to me, is of extreme importance because corrective policies will focus on attitudes, loyalties, cultural values, etc. of both the affected group and of the dominant society, avoiding the fact that these are only reflections of the material conditions which have created them.

\section{HYPOTHESIS}

1) The language of modern Gitanos, except for a relatively few lexical items derived from the traditional Romani, is essentially the same as the Spanish vernaculars of the areas where they live; and

2) The Gitanos' social and educational marginality is founded on their relation to production rather than on their language differences with the Spanish majority. In Section 3 I shall present evidence in favor of the stated hypothesis.

\section{CASE STUDIES}

This section consists of data based on tape-recorded interviews of two adult male Gitanos in Barcelona -1) R.M., an activist of Ronda San Martín, better known 


\section{LANGUAGB, MARGINALTTY AND BDUCATION}

as "La Persona", a Gitano neighborhood in urban Barcelona; and 2) J.R., an offloe employee of Barcelona's housing authority, Patronato Muncipal de la Vivienda

The interviews were not designed to elicit data for statistical analysis; rather, their structure consists of informal conversation-I asked general questions about the informants' history, occupation, education, family and ancestry, etc. The informants' answers constitute the evidence for my hypotheses in Section 2.

Since R.M. generally reflects the Gitano condition more typically than does J.R., I shall place the main emphasis of my study on the former.

\section{Case study: R.M.}

Personal and family background. At least on his mother's side, R.M., age 27, is a Cafelete, i.e. a Gitano born in Barcelona of Bético, i.e. Andalusian, background. With regard to his father, R.M. only knows that he was aFrench Kalderash (a term referring to another branch of the Rom, to which Gitanos are also related) who returned to his homeland shortly after R.M. was born. From his father's side, R.M. has no knowledge of his linaje or family background. His recognized linaje, as stated to me, it that of his mother, now deceased, and of his mother-in-law.

Married, with one child, R.M. reflects the marginality of Gitanos in Spanish society. He lives with his family in "La Persona", a chabola or slum in urban Barcelona. With little formal education, he is nevertheless relatively fortunate to be employed as a community liaison with Barcelona's Patronato Municipal de la Vivienda, earning enough, in his own words, "para comer bien o mal" ("to eat well or poorly").

But R.M. is a fighter. Rather than accept the decisions of his supervisors blindly, he will stand firm on what he thinks is right regardless of the consequences with his job. This has eamed him a reputation as community leader.

Housing. La Persona has approximately 700 inhabitants, almost all Gitanos, constituting 90 to 100 families. It is surrounded on all but one side by aPayo or nonGitano residential district. On the fourth side is a railroad yard.

La Persona's origins date back to the early 1940's, when, after the Civil War, emigrants from other parts of Spain settled in Barcelona. Initially a Payo community, Ronda San Martín was nicknamed "La Persona" after Eva Duarte de Perón, the wife of then-president of Argentina, Juan Perón, visited thechabola in 1947 and offered her support in the building of better housing for its residents.

Subsequently, the original Payo chabolistas of La Persona, receiving preferential treatment from Spanish society in general, gradually mowed out to better 
housing. Other, Gitano chabolas, at the same time, were razed, the inhabitants herded into trucks with only "cuatrotrapos" (i.e. a few belongings), and relocated in La Persona. Although the present government has become more concerned about housing, the problem still persists.

Gitano culture must also be taken into account in the solution of the housign problem. Gitanos, originally a nomadic people, have been forced to lead sedentary lives and there are few Gitano nomads left in Spain. The culture of these sedentary Gitanos, however, still recalls their nomadic past. Gitanos prefer to live in open rather than in enclosed spaces.. "que nos de el aire en la card" ("so the wind will blow in our faces"). They would rather occupy viviendas horizontales (single-story housing) than verticales (multiple-story). This has given rise to the anecdote among Payos that a Gitano, when he move into an apartament building, will bring in his horse or donkey along with his family, even if he lives on the third or fourth floor.

Living conditions. Although born in the 1960's, a period of the Spanish economy which R.M. compares favorably with the present, the living conditions of Gitanos were not much better then than are now. R.M. was born "en la calle" -out in the open. Gitano babies at that time were not generally born in hospitals. R.M.'s mother did not wear shoes until she was 45 . The family normally ate only one meal a day.

From personal observation, I believe conditions for Spanish Gitanos today are materially, although not qualitatively, better. Ronda San Martín, the street along which La Persona is situated, is paved, although poorly, with stagnant water in its many pot holes. In the summer, many of the adults along with their children conduct a major part of their daily lives out in the street. Although some of the residents drive automobiles, usually older models, I saw no horses or donkeys.

Obra Social San Martín, a clinic run by Catholic nuns, provides much of La Persona's health care. The nuns also provide other social service. It was through the help of Sor Pilar Lopez of this clinic that I was able to make contact with my informant R.M.

Education. Education for Gitanos in Barcelona did notbegin seriously until the 1970 's. It did not come willingly on the part of officialdom. As with the housing problem, however, the Gitano education problem cannot be resolved without taking Gitano culture into account as well. Gitanos have traditionally considered Payo education of little value to them unless they can see immediate, tangible benefits therefrom, which is generally not the case. Education, however, although generally irrelevant to a nomadic people of the past, is now indispensable for Gitano progress. At. the same time, it needs to be made relevant to Gitano needs. 
In the early 1970 's La Persona, by then a totally Gitano community, had grown to over 4,000 residents. Some form of schooling became necessary. The first efforts were made by two Paya women in 1972, who began teaching voluntarily out in the street. That was the beginning of R.M.'s education. The police soon put an end to it, however, by detaining the Payas (the women) for teaching without a permit.

Eventually, however, two or three school buildings were erected and fomal schooling for La Persona was instituted. But even that was not enough for La Persona's inflated population at the time (J.R., my other Gitano informant, has stated that even today education in La Persona is far inferior to Payo standards: a seventh or eighth grade education in Los Pinillos, the school in La Persona, has been rated as equivalent to third grade when La Persona students have transfered to Payo schools).

\section{Case Study: J. R.}

Aged 40, J.R. came to Barcelona from his native Seville 16 years ago. Relatively well educated, he is presently an office employee at Barcelona's housing authority, Patronato Municipal de la Vivienda. His life in Barcelon is suspended between two cultures: although extremely proud of his Gitano culture and values, his daily activities revolve mostly around non-Gitanos. Wishful of finding a companion and getting married, he nevertheless feels that neither a Gitana nor a Paya could fulfill his needs completely: a Gitana would not understand his Payo ways and a Paya would not understand his Gitano ways.

The linguistic data from both J.R. and R.M. will be discuissed in the following section.

\section{LANGUAGE}

Serious research on the language of the Gitanos is meager (some examples: Clavería, 1951; Wagner, 1924, 1936, 1937 and, on the related Ciganos of Portugal, 1949). Most of the published works consist of vocabulary lists without rigorous lexicographical criteria -e.g. Rosensweig (1972), Jung (1972), etc. Nevertheless, I develop the following analysis of my two informants' speech on the hypothesis -based on Claveria (1951)-that the language of the Gitanos is essentially the same as the Spanish vernacular of the surrounding community except for the inclusion of a relatively few lexical items derived from Romani, the traditional language of the Rom, which has its remote origins in India. This Gitano variety of Spanish is what is commonly referred to as Calb.

R.M.Except for his careful and accurate distinction between $/ \mathrm{s} /$ and $/ \varnothing /$, which, in Adalusian Spanish, are usually merged into one or the other of these two 
phonemes, R.M.'s speech, like that of other Cafeletes, to a greater or lesser degree reflects his Andalusian background.

Syllable final $/ 1 /$, for example, is sometimes realized as [r], although not in all syllable final environments as in the Andalusian dialects which have this feature. Instead, R.M.'s rule seems to be restricted to the environment/_d; e.g. $f a[r] d a$, st. Sp. fa[1]da 'skirt'; to[r]do, st. Sp. to[l]do "tent"; fa[r]diquera (if we accept this lexeme as equivalent to st. Sp. $f a[1] d r i g u e r a$ "woman's bag tied around the waist", with deletion of the second, post-consonantal /r/; but not in a [1]guien "someone", e[1]gitano "the Gitano", e[1]turismo "tourism", etc., all as in st. Sp.

Furthermore, even in the environment $/-\mathrm{d},[\mathrm{r}]$ for $/ /$ doesn't occur in all Instances; e.g. e[1]dia" "the day", $k a[1]$ derash "kalderash". In the latter example one might argue that R.M.'s realization [1] for $/ 1 /$ is due to the fact that kalderash is a loan word and thus is not part of the Andalusian vemacular. Other example in my corpus, nervertheless, cannot be explained in this way. Thus the environment of R.M.'s rule must be stated in lexical as well as phonological terms.

Although my corpus is too small to investigate this question more thoroughly at this time, it may be that living in Barcelona rather than in Andalusia has influenced R.M. to consciously strive to modify his speech in this respect but without acheiving it in all cases. This conscious effort to realize /1/ as [1] would account for the exceptions in his speech to the Andalusian rule that realizes $/ 1$ / as [r]. The specific reasons for the highly selective phonological and lexical environment of R.M.'s rule, however, remain enigmatic.

J.R. Linguistically speaking, J.R. is clearly more Andalusian than R.M. The st. Sp. phoneme $/ \mathrm{s} /$ and $/ \varnothing /$ are obviously merged into a single phoneme, a recognized Andalusian feature. In J.R.'s speech, however, the phonetic realization of this phoneme follows a quite complex pattern: in syllable final position it is regularly realized as [h]; e.g. cono[h]ca, st. Sp. cono[ø]ca "I may know"; $e$ h], st. Sp. $e[\mathrm{~s}]$ "is"; mi[h]mo, st. Sp. mi[s]mo "same"; etc. Exceptions seem to reflect a more careful style, as when citing an example of Gitano speech and its standard Spanish gloss; e.g. lo[s] ojo[h]; dicló[s] o sacái[s] "the eyes".

Notice in this example that both the st. Sp. gloss and its corresponding Calo citation have two instances of J.R.'s archiphoneme -which I shall represent as /s/ -yet only in the Caló citation are both instances clearly realized as [s] -diclós] o sacái[s]. In J.R.'s st. Sp. gloss, on the other hand, only the medial /s/ is realized as [s]; the phrase final/s/ (followed by a slight pause) is realized in J.R.'s customary manner as [h] $l o[s] ~ o j o[h]$. There is a phonological reason for this difference: the first $/ \mathrm{s} /$ is intervocalic and is joined in discourse to the following syllable - -0 - [s]o$j o[h]$. Thus it is, prosodically speaking, in syllable initial position and therefore not affected by the Andalusian $/ \mathrm{s} / \rightarrow[\mathrm{h}]$ rule. 
The second $/ \mathrm{s} /$, on the other hand, is definitely in syllable final position and therefore has the expected Andalusian realization [h]. The fact that J.R. maintains a strict [s] to /s/ correspondence in diclo[s] y o sacái[s] but not in $l o[s] ~ o j o[h]$ suggests that even his careful speech becomes relaxed when he reaches the end of a Spanish -but not a Calo- phrase.

In prevocalic position, J.R. realizes his archiphoneme /s/ as somewhere between [ø] and [s] -the stridency of this variant is somewhat less marked that in st. Sp. [s]. The auditory impression, consequently, is more towards [ø] than [s]. I shall therefore transcribe it as [ø] (with the caveat that is not identical to st. Sp. [ø] -e.g. di[o]e "says", /Bar [o]elona "Barcelona", Andalu[ø]ía "Andalusia",

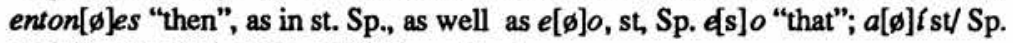

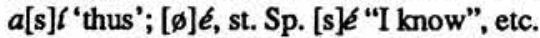

\section{SUMMARY AND CONCLUSIONS}

In this section I shall recapitulate and conclude my arguments concernig the two hypotesis in Section 2, namely

1) The language of modern Gitanos, except for a few lexical items derived from the traditional Romany, is essentially the same as the Spanish vernacular spoken in the area where they live; and

2) Gitano educational and social marginality is founded on their basic relation to production rather than on their language differences with the Spanish majority.

With respect to the first hypothesis, the only evidence I can present in this study is my informants' own attestations. Clavería (1951), however, conducted a thorough study of this problem and came to the same conclusion. It should be qualified that presently there is a renaissance of the traditional language in the Gitano movement -Nevipens romani, for example, is presently publishing installments of the Spanish constitution translated into Cal6, as it prefers to call the Gitano traditional language. Outside of those active in the movement, nevertheless, it is doubtful that many Gitanos have knowledge of their traditional language other than of the few lexical items already mentioned.

The loss of the Gitanos' traditional language is obviously related to their forced "integration" into Spanish society. The fact that they retainsome lexical items from their traditional language is an indication that they are not yet fully integrated.

As the data from my case studies suggest, however, it is doubtful that the elimination of language differences altogether between Gitanos and Payos, in the direction of a more standard variety, will assist in the formers' progress toward 
educational and social equality. In microcosm, this is evidenced by the differences in speech between J.R. and R.M.: in spite of his uninhibited use of clearly Andalusian vernacular, J.R. has had more educational and social mobility than R.M., who conforms more to the norms of standard Spanish.

Probably not by coincidence, there is a striking parallesim between this example and that of Chicanos in the United States: it is a general observation that Chicanos who identify with heritage insist on speaking English with the overtones of their home language -an "interlanguage" or bled of Spanish and English. Thus, code-switching, borrowing and other bilingual phenomena are part and parcel of the English variety spoken by Chicanos, including university professors, students and other educated members of this ethnic group. ${ }^{2}$ The use of this nonstandard variety, apparently, has not kept some Chicanos, at least, from attaining their educational goals.

Wherein, then, does the path to educational equality for ethnic minorities lie? Generalizing my hypothesis (2) above to apply to Chicanios as well, I conclude that whatever progress Chicanos have made in this direction lies not in their accomodation to the linguistic and other norms of the mainstream society but rather in their wresting power, however limited, from that mainstrem. Educated Chicanos today can afford the luxury of speaking their vernacular even in "mixed, company" because their interests are institutionally protected (again, however limited). Take away these institutional guarantees and we go back to square one.

Gitanos, for reasons beyond the scope of the present study, have not followed the Chicano example. Their movement for social justice is visible, particularly since Franco's death, but its approach has been persuasive rather than confrontational. Accordingly, its gains have been more limited. Every issue of Nevipens romant, the movement biweekly based in Barcelona, for example, is replete with instances of bare-faced discrimination against Gitanos. Gitanos are still openly barred from schools, employment, business establishments, etc. simply because of their race. Based on the social and linguistic data obtained through my case studies in Barcelona, I believe Gitano lingustic adaptation in the direction of standard Spanish would do little to alleviate this situation.

In summary, Gitanos have gone a long way in their adaptation -including language- to Payo ways, but educational as well as other forms of equality are still an elusive goal of the future. The contribution of the present case study, I believe,

\footnotetext{
${ }^{2}$ For further discussion of Chicago language -specifically the English variety- see Omstein-Galicia (1983) and Pennfield \& Omstein-Galicia (1985).

${ }^{3}$ Even Anglo Americans have adopted some of the expressions typical of Chicago English: recently an Anglo host in a TV program, for example, stated that he would present the news" ... and the whole enchiland".
} 
has been to present evidence and arguments suggesting that the solution to this problem lies not in a marginal group's linguistic conformism with the mainstream but rather in a basic realignment of the group's relation to production. The Rom are presently organizing a movement for equality the world over. Ultimately, Ibelieve, they will have to recognize the structural foundation of their condition and develop strategies for changing it.

\section{REFERENCES}

CLAVERIA, C. 1951. Estudios sobre los gitanismos del español. Madrid: Consejo Superior de Investigaciones Científicas.

DONAHUE, T.S. in press. "The functionalist perspective of the family in the sociology of language: An axiom". in Texas Linguistics Forum: Proceedings of NWAV XVI [Austin, October 1987].

ESCOBAR, A. 1972a. Lenguaje y discriminación en América Latina.. Lima: Instituto de Investigaciones.

1972b. El reto del multilingüismo en el Perú. Lima: Instituto de Estudios Peruanos.

FISHMAN, J. G.D. Keller, and (eds.). 1982. Bilingual education for Hispanics in the United States. New York: Teachers College Press, Columbia University.

JUNG, C. 1972. Wortliste des Dialekts der spanischen Zigeuner (Cal6-SpanischDeutsch). Mainz: Flamenco Studio.

LEAP, W. L. 1984. “American Indian languages”. In. C. A. Ferguson \& S.B. Heat (eds.). Languages inthe USA. New York: Cambridge University Press.

LEBLON, B. 1987. Los gitanos de España: El precio y el valor de la diferencia. Translated from the French by Irene Agoff. Barcelona: Editorial Gedisa, S.A.

S/A Newspaper Nevipens romani, "Noticias gitanas". Baños Nuevos 16, Barcelona, Spain.

OHMANN, R. 1987. "Reflections in class and language". In H.B. Allen \& M.D. Linn. Dialect and language variation. New York: Academic Press, Inc.

ORNSTEIN-Galicia, J. (ed.). 1983. Form and function in Chicano English.

PENNFIELD, J. \& J. Ornstein-Galicia, (eds.). 1985 Chicano English: An ethnic contact., Philadelphia: John Benjamin.

RAMIREZ Heredia, J. de Dios. 1983. Nosotros los gitanos (4th ed.). Barcelona: Ediciones 29. 1985. En defensa de los míos. Barcelona: Ediciones 29.

ROSENSWEIG, J. B. 1972. Cal6: Gutter Spanish New York: E.P. Dutton and Co., Inc.

SAN ROMAN, T. 1976. Vecinos gitanos. Barcelona: Akal Editores.

SKUTNABB-Kangas, T. 1981. Bilingualism or not: The Education minorities Multilingual Matters Series, Vol. 7. Stockholm: Multilingual Matters Ltd.

TORRES Fernández, A. 1987. Los gitanos somos una nación: Lapsicología social del pueblo gitano y su perspectiva de estado. Barcelona: Ediciones Romani. 
WAGNER, M.L. 1924. Notes linguistiques sur l'argot barcelonais. Barcelona. 1936. Stray notes on Spanish Romani. Journal of the Gypsy Lore Society, Third Seies, 15. 1937 Stray notes on Spanish Romani. Journal of the Gypsy Lore Society, Third Series, 16.

1949. O elemento cigano no caloa e na linguagem popular portuguesa: Miscelanea de la filosofia, literatura e historia cultural a memoria de Francisco Coelho. Lisbon.

WILLIAMS, R.M. Jr. 19789. American Society (3rd. ed.) New York: Knopf. 